\title{
Interdisciplinary research approaches to address complex forest management issues
}

\author{
by Walt Klenner ${ }^{1}$ and Alan Vyse ${ }^{2}$
}

\begin{abstract}
We examine the role of interdisciplinary research projects in providing information to forest managers about complex and longterm responses by forest ecosystems to managed and natural disturbances. Traditional research approaches focus on identifying issues, implementing the appropriate experimental design, conducting the work and disseminating information through peerreviewed articles or internal manuscripts. Such independent studies can provide information about a specific issue, but do not necessarily consider long-term impacts or effects on multiple resources. Interdisciplinary research installations that focus on basic ecological processes, while addressing some operational issues of interest to managers can be used to complement traditional research programs. The Sicamous Creek silvicultural systems experiment in the Kamloops Forest Region, British Columbia is used as an example of such a project. We identify some of the benefits that large scale interdisciplinary projects have, how they complement traditional approaches, some of the challenges these projects face, and the administrative changes that should be undertaken to provide an environment in which such projects can develop.
\end{abstract}

Key words: ecosystem research, long-term ecological research, interdisciplinary research, forest management
Nous examinons le role des projets de recherche interdisciplinaires sous l'angle de l'apport d'information aux gestionnaires forestiers relativement aux reactions complexes et a long terme des ecosystemes a amenager et suite a des perturbations naturelles. Les approches traditionnelles en recherche sont centrees sur l'identification des problemes, la mise en place du design experimental approprie, la realisation du travail et la dissemination de l'information par l'entremise d'articles revises par des pairs ou par des publications internes. Ces etudes independantes peuvent fournir de l'information sur des questions specifiques, mais ne considerent pas necessairement les impacts a long terme et les effets sur plusieurs ressources. Les installations de recherche interdisciplinaire qui sont centrees sur les processus ecologiques fondamentaux, tout en repondant a certaines questions operationnelles d'interet pour les gestionnaires, peuvent etre utilisees pour completer les programmes traditionnels de recherche. Le projet de systemes sylvicole de Sicamous Creek dans la region forestiere de Kamloops en Colombie-Britannique, est utilise a titre d'exemple d'un tel projet. Nous identifions certains des benefices tires des projets interdisciplinaires a grande echelle, comment ils completent les approches traditionnelles, certains des defis auxquels font face ces projets, et les changements administratifs qui devraient etre entrepris pour etablir un environnement dans lequel de tels projets peuvent se developper.

Mots-cles: recherche ecosystemique, recherche ecologique a long terme, recherche interdisciplinaire, amenagement forestier

\section{Introduction}

With increased interest in the management of public forests, and new legislation that requires practices to meet certain standards (e.g., the Forest Practices Code: British Columbia Forest Service and British Columbia Environment 1995), the role of technical information derived from research programs designed to help guide the management of forests and other ecosystems has never been more critical. Traditionally, forest management practices have largely been guided by classic silvicultural approaches (e.g., Smith 1986) or specific studies designed to address an issue. However, as public demands for sustainable forestry or ecosystem management approaches increase (Pedersen 1996), traditional perspectives no longer suffice and new approaches need to be examined. Baskerville (1994) summarized some of the gaps between research activities and operational forestry activities, noting that there is neither a shortage of research or operational activities, but that the former does not necessarily help the latter. With concepts like integrated resource management and ecosystem management requiring the simultaneous consideration of multiple values, the situation may get worse before it gets better.

\footnotetext{
${ }^{1}$ Wildlife Habitat Ecologist, British Columbia Ministry of Forests, 515 Columbia St., Kamloops, B.C. V2C 2T7. E mail: Walt.Klenner@gems7.gov.bc.ca ${ }^{2}$ Research Group leader, British Columbia Ministry of Forests, 515 Columbia St., Kamloops, B.C. V2C 2T7. E -mail: Alan.Vyse@gems1.gov.bc.ca
}

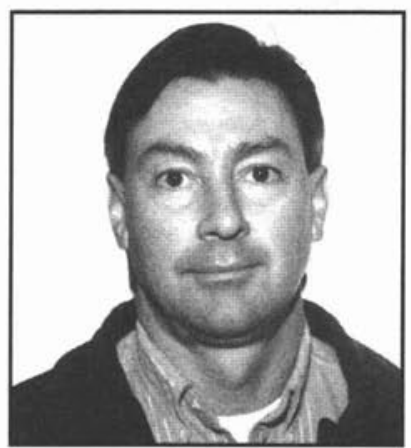

Walt Klenner

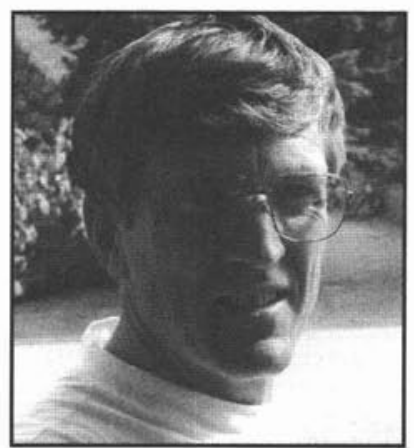

Alan Vyse
Some of the dysfunction in the research-operational marriage relates to a genuine lack of understanding with respect to what research efforts provide and what operational applications need. In our experience, there is much room for expanding the dialogue between research and operational staff to harmonize expectations and develop realistic deliverables for research. Three key changes would facilitate this process: 1. A strong commitment to base management decisions on sound information. When this information does not exist, recognize the gaps in knowledge and initiate programs to address key issues. 
2. Develop a commitment to aggressively undertake a "learning by doing and monitoring success and failure" adaptive management approach (Walters and Holling 1990, Taylor et al. 1997) to managing forested ecosystems, and

3. Encourage the research community to focus not only on reporting what should not be done or what should be done, but to interpret their applied research in the more complex reality of operational issues, and to consider how to apply the results.

The frayed communication between operational foresters and researchers may stem from the singular focus of many research projects. Although carefully designed experiments may provide precise results, the very nature of singular studies or reductionist designs may limit their applicability to operational issues because they lack realism (Baskerville 1994). An example of the complex, interdisciplinary decisions of operational forestry can be found in the requirements of a silviculture prescription in British Columbia (British Columbia Forest Service and British Columbia Environment 1995). Silviculture prescriptions need to consider soils, wildlife, fisheries, watershed impacts, range, recreation, visual impacts, disease and insect pests, the harvesting system, site regeneration and proposed stand tending entries. Research that is developed, executed and published without regard for the complex operational environment may not only be of little value, it may impede or confuse the development of innovative silvicultural practices by recommending approaches that contradict and are unacceptable to other resource issues.

Although complex, research approaches to address operational or social questions are necessary not only to help inform administrators and managers about the potential outcomes of their actions, but to maintain societies trust in the value of science (Hobbs et al. 1983, Larson 1996, Lubchenko 1998). Here, we explore the utility of long-term, large-scale research approaches in increasing our understanding of ecosystems. We draw on experience gained at the Sicamous Creek silvicultural systems site to illustrate some of the benefits of an extension of this approach, the application of interdisciplinary teams to address basic and applied forest management issues.

\section{Long-term Studies in Ecology}

The role of long-term studies in ecology and the complementary approach of using large ecosystem scale experiments has received much attention in recent years (Swank and Crossley 1988, Likens 1989, Magnuson 1990, Long-Term Ecological Research Network 1993, Carpenter et al. 1995). The role such studies have played in elucidating critical ecological processes and ecosystem responses to disturbances is well documented. For example, our understanding of biogeochemical and hydrological processes at large scales has been facilitated by the long-term studies at Hubbard Brook and Coweeta (Likens and Bormann 1995, Swank and Crossley 1988). Similarly, much of our knowledge about the effects of acid rain and nutrient addition on lake ecosystems stems from detailed, long-term work at the Experimental Lakes area in Ontario (Schindler 1988). Other long-term studies have helped to formulate environmental policy (Rasmussen and Wright 1998 ) or understand population and community dynamics in a boreal forest ecosystem (Krebs et al.1996). Further examples are reported in Likens (1989).
Franklin (1989) outlines several ecological issues for which long-term studies are necessary. These include tracking slow processes, observing rare or episodic phenomena, processes with high variability and complex phenomena. There is some opportunity to replace long-term studies with chronosequence (also known as "space for time") investigations, but there are many shortcomings to this approach. Pickett (1989) concluded that space for time investigations are appropriate for establishing general qualitative trends, but that past historical patterns may confound results and make time series investigations more appropriate where hypotheses are being tested or ecological processes are the focus of the study. The importance of conducting time series measurements is especially important where the phenomenon being investigated changes slowly or may be influenced by stochastic processes (Franklin 1989, Pickett 1989). For example, a time series study would be appropriate for examining the processes that drive forest succession following a disturbance such as clearcutting or wildfire.

We conducted a brief review of the recent literature on field studies to determine the general nature of work currently being published. A total of 1303 articles published between 1996-98 were reviewed, of which only 165 fit our criteria of being a field ecology study. The following journals were surveyed: Canadian Journal of Forest Research, Conservation Biology, Ecological Applications, Ecology, Forest Ecology and Management, Forest Science, Scandinavian Journal of Forestry, Journal of Applied Ecology, and Journal of Wildlife Management. We evaluated whether the studies were chronosequence or time series in nature, the period of investigation, whether the study re-measured a previously studied installation, and whether the results were part of an interdisciplinary initiative to quantify several issues. Thirty-five percent of the studies were reports from time series studies of greater than three years duration, but only $3 \%$ of the publications represented time series re-measurements of studies initiated more than 20 years ago. Eleven percent of the reports addressed more than two research issues and therefore qualified as interdisciplinary. However, when this definition of interdisciplinary was restricted to include only studies that addressed issues from three or more disciplines (e.g., harvest treatment, windthrow and habitat use by wildlife), only two of the studies $(<2 \%)$ possibly qualified. This brief survey of published articles may not have been an adequate sample of published field ecology studies, the journals we surveyed may be a biased sample, and we encountered some difficulty in assigning publications to categories. However, our results are consistent with Baskerville's (1994) observations about the large body of research which does not address operational issues, with only a small proportion of the published studies representing re-measurements of long-term studies, and fewer still addressing the multidisciplinary nature of applied ecology.

The paucity of published research on programs designed to address the complex nature of ecosystems, and operational forestry issues is remarkable. It is generally recognized that ecosystems are extremely complex and variable in their response to disturbances, yet the literature is dominated by reports that address singular issues, are widely dispersed across different ecosystems, or which relate findings primarily to complementary aspects of the same issue. Are other disciplines dominated by the same approach? Examples of multidisciplinary team 
approaches to the solution of complex issues like the making of the first atomic bomb (the "Manhattan Project") or automobile design suggest otherwise, or at least the use of a more balanced approach to conducting research. A critical review and evaluation of the current approach to applied ecological research, coupled with a strategic research planning exercise may yield important insights and some answers to the questions raised by Baskerville (1994).

\section{Lessons from the Sicamous Creek Project}

The Sicamous Creek project (see Hollstedt and Vyse 1997, and Vyse 1999, for descriptions) is an interdisciplinary study of applied and basic ecological issues in a high elevation ecosystem. The project was initiated in 1990 and shares many of the technical, conceptual, implementation and funding strategy challenges reported by other investigators (this volume). There was an a priori objective of providing information to help guide operational issues including forest regeneration, harvest costs associated with alternatives to clear cutting, watershed impacts, root disease and insect pests, floral and faunal biodiversity and visual impacts, among others. Five gap size treatments (no harvest, uniform individual tree selection, and $0.1,1.0$ and 10.0 ha openings) were combined with four ground disturbance treatments (none, mounding, broadcast burn, complete organic layer removal) in a split-plot design instead of conventional or currently popular management treatments.

In addition to the operational issues indicated above, this simple replicated design created a range of disturbance intensities or gradients that facilitated investigations into several basic ecological concepts. For example, researchers are studying microclimate and energy flux across openings, vegetation succession in relation to disturbance intensity and gap size, soil nutrients and disturbance, and the habitat requirements of several indicators of faunal biodiversity.

This project is already yielding some short-term operational benefits. Information on seedling survival in different-sized gaps and with different ground disturbance, windthrow in relation to gap size, slash management procedures to protect riparian habitat along small streams, and the importance of snags and downed wood to wildlife are examples of information that can be used to modify management prescriptions in the shortterm. Although not thoroughly tested, these lessons have now passed the first screening and are good candidates for testing at a more extensive scale using an adaptive management approach.

An additional, non-trivial benefit of this approach is the development of a compact facility where operational staff can be briefed on the implications of the different treatments on a range of issues, all at one site. These tangible benefits are complemented by several less tangible ones that can only be derived from an interdisciplinary team environment. For example, the increased awareness amongst scientists of issues outside their field of inquiry can substantially diminish the problem of conflicting messages in an extension program.

\section{Future Challenges}

Despite the benefits that large-scale multidisciplinary projects offer, there are several challenges that need to be overcome. The following is a brief summary of six key issues that need to be addressed to develop the full potential of these types of sites.
1. Research activities are not always integrated physically or conceptually, and although studies are conducted at the same site, different issues may be examined and interpreted in isolation. This issue is exacerbated by multiple funding agencies, or the lack of a coordinated approach to the funding of large interdisciplinary projects.

2. Complex research results that demonstrate conflicts or contradictions between disciplines are difficult to interpret or develop into a simple message. This is to be expected, since it would be unrealistic to expect one magical treatment that satisfies all issues, yet an extension mechanism to reconcile such possible conflicts as improved tree growth and the loss of critical habitat structures for wildlife is sorely needed. Landscape planning, and the application of landscape planning models may help to develop the appropriate mix of treatments to satisfy diverse objectives across the landscape (e.g., Crow and Gustafson 1997, Klenner et al. 1997).

3. A reward system to encourage researchers to participate in large-scale multidisciplinary endeavours needs to be implemented. Compromising the perfect design, working at the less-than-perfect site, investing effort towards the delayed payoff that a time series investigation represents, tolerating the restrictions posed by adjacent or overlapping studies, all need to be offset with some recognition if excellent researchers are to be attracted to these facilities. This issue has received much attention in the literature (Hobbs et al. 1983, Franklin 1989, Lubchenko 1998), but progress to date by research agencies is not obvious.

4. Finding a balance between basic ecological investigation and operational needs continues to be a challenge that may never have a perfect solution. However, the recognition that both issues exist, and initial considerations to accommodate both approaches is a step in the right direction. Simple, robust experimental designs with clear linkages to operational issues help create an infrastructure and environment where diverse research interests on fundamental issues can coexist with operational investigations, and which will continue to provide information of long-term interest to science and society.

5. Developing complementary satellite projects, or linking a large-scale interdisciplinary project to existing studies can help verify the results gained at a single location, and would help ensure the suitability of a treatment for wider application. The choice of indicators to measure at these complementary installations needs to be carefully considered and matched to the ecological processes being examined.

6. Funding to either establish a long-term interdisciplinary trial, or to ensure continued funding so that the installation becomes a long-term trial, is always a problem. The stochastic nature of research funding ensures that there will always be pressures to terminate or delay implementing long-term projects, but several approaches can buffer this uncertainty. Monetary endowments or land trusts from which revenues independent of annual budgets can be derived to support the research program are one (albeit unlikely) option. A second approach is the development of a research planning strategy that establishes the need for long-term investigations and balances this approach with conventional, independent studies. Research agency man- 
agers need to address this challenge based on agency needs, a vision for the type of program that will most likely deliver these products, and the management or political will to articulate and defend the strategy. The alternative of simply funding good scientific studies is easier to apply, but provides little assurance that operational issues will be addressed.

\section{Acknowledgements}

We would like to thank S. Boutin and I. Cameron for their contributions to the ideas discussed in this manuscript. J. Shatford helped survey the recent ecological literature. J.T. Arnott and an anonymous reviewer provided helpful review comments on an earlier version of this manuscript.

\section{References}

Baskerville, G.L. 1994. Gaelic poetry for deaf seagulls - encore. For. Chron. 70: 563-564.

British Columbia Forest Service and British Columbia Environment. 1995. Forest Practices Code Regulations. Queens Printer, British Columbia. 261 p.

Carpenter, S. R., S.W. Chisholm, C.J. Krebs, D.W. Schindler and R.F. Wright. 1995. Ecosystem experiments. Science 269: 324-327. Crow, T.R. and E.J. Gustafson. 1997. Ecosystem management: managing natural resources in time and space. In K.A. Kohm and J.F. Franklin (eds.). Creating a forestry for the $21^{\text {st }}$ century: the science of ecosystem management. pp. 215-228. Island Press, Washington, D.C.

Franklin, J.F. 1989. Importance and justification of long-term studies in ecology. In G.E. Likens (ed.). Long-term studies in ecology: approaches and alternatives. pp. 3-19. Springer-Verlag, New York.

Hobbs, S.D., J.C. Gordon and G.W. Brown. 1983. Research and technology transfer in southwest Oregon. Journal of Forestry 81: 534-536. Hollstedt, C. and A. Vyse (eds.). 1997. Sicamous Creek silvicultural systems project: workshop proceedings, April 24-25, 1996. Kamloops, BC. Research Branch, BC Ministry of Forests, Victoria BC, Working Paper 24/1997. 283 p.

Klenner, W., W.A. Kurz and T.M. Webb. 1997. Projecting the spatial and temporal distribution of forest ecosystem characteristics. In Conference proceedings, GIS '97: Integrating spatial technologies for tomorrow. pp. 418-421. GIS World, Ft. Collins, CO.
Krebs, C. J., A.R.E. Sinclair and S. Boutin. 1996. Vertebrate community dynamics in the boreal forest of north-western Canada. In R.B. Floyd, A.W. Sheppard and P.J. De Barro (eds.). Frontiers of population ecology. pp. 155-161 CSIRO Publishing, Melbourne. Larson, W.E. 1996. The importance and need for interdisciplinary research and programs. Renewable Resources Journal. 14: 21-23. Likens, G.E. (ed.) 1989. Long-term studies in ecology. Springer-Verlag. $214 \mathrm{p}$.

Likens, G.E. and F.H. Bormann. 1995. Biogeochemistry of a forested ecosystem (second edition). Springer-Verlag, New York. 159 p. Long-Term Ecological Research Network. 1993. National research sites with a common commitment. U.S. LTER Network Office, University of Washington. Seattle, WA. 8 p.

Lubchenko, J. 1998. Entering the century of the environment: a new social contract for Science. Science. 279: 491-497.

Magnuson, J.J. 1990. Long-term ecological research and the invisible present. BioScience 40: 495-501.

Pedersen, L. 1996. Sustainability in the crucible of competing demands. Forestry Chronicle. 72: 609-614.

Pickett, S.T.A. 1989. Space-for-time substitution as an alternative to long-term studies. In G.E. Likens (ed.). Long-term studies in ecology: approaches and alternatives. pp. 110-135. Springer-Verlag, New York.

Rasmussen, L. and R.F. Wright. 1998. Large-scale ecosystem experiments: ecological research and European environmental policy. Forest ecology and management. 101: 353-363.

Schindler, D.W. 1988. Experimental studies of chemical stressors on whole lake ecosystems. Verh., Int. Ver. Theor. Angew. Limnol. 23: $11-41$.

Smith, D.M. 1986. The practice of silviculture. John Wiley and sons. New York. 527 p.

Swank, W.T. and D.A. Crossley, Jr. (eds.). 1988. Forest hydrology and ecology at Coweeta. Springer-Verlag, New York. 469 p.

Taylor, B., L. Kremsater and R. Ellis. 1997. Adaptive management of forests in British Columbia. BC Ministry of Forests, Forest Practices Branch, Victoria, BC. 93 p.

Vyse, A. 1999. Is everything all right up there? A long-term interdisciplinary silvicultural systems project in a high elevation firspruce forest at Sicamous Creek, B.C. For. Chron. 75: 467-472.

Walters, C.J. and C.S. Holling. 1990. Large-scale management experiments and learning by doing. Ecology. 71: 2060-2068. 